С. Д. Бушусв, д.т.н., професор, завідувач кафедри управління проектами, e-mail: sbushuyev@ukr.net

А. В. Пузійчук, аспірант, e-mail: a.puziichul2018@meta.ua

Київський національний університет будівництва і архітектури, просп. Повітрофлотський, 31, м. Київ, 03037, Україна

\title{
ПОДАЛЬШИЙ РОЗВИТОК МОДЕЛЕЙ І МЕТОДІВ ПРОЕКТНОГО МЕНЕДЖМЕНТУ ДЛЯ ЦІННІСНО-ОРІЄНТОВАНОГО УПРАВЛІННЯ ПРОЕКТАМИ РЕІНЖИНІРИНГУ БУДІВЕЛЬНИХ КОМПАНІЙ
}

Підкреслено значення будівельної галузі для розвитку економіки. Визначено важливість проектів реінжинірингу для забезпечення конкурентоспроможності будівельних компаній. Проведено аналіз літературних джерел за трьома напрямами: стандарти і дослідження у галузі управління проектами і програмами; иіннісний підхід; проекти реінжсинірингу процесів управління. Запропоновано тріадний підхід «проектність-иінність-реінжиніринг». Виділено напрями розробки кожного з елементів тріадного підходу «проектність-цінністьреінжиніринг» для будівельних компаній. У першому елементі - ие інтеграція через Agile, y другому - життєвий иикл цінностей, у третьому - пелюстковий реінжиніринг. Запропоновано кроки методу «пелюсткового реінжинірингу», проведено SWOT-аналіз методу. Зроблено висновок щодо збільшення гнучкості системи управління будівельними компаніями завдяки впровадженню методу «пелюсткового реінжинірингу». Окреслено перспективи подальших досліджень в обраному напрямі.

Ключові слова: управління проектами, ціннісний підхід, реінжиніринг, пелюстковий реінжиніринг.

Вступ. Будівельна галузь $\epsilon$ одним із локомотивів розвитку економіки. Успіх і розквіт будівельної галузі створює передумови успіху і розквіту економічної системи країни. Отже, будівельні компанії і підприємства мають відповідати сучасним вимогам ринку з точки зору застосовуваних ними як будівельних, так і управлінських технологій. Водночас не усі підприємства будівельної галузі використовують передові технології, багато з них і нині застосовують застарілі рішення (особливо у сфері управління), користуючись інертністю ринку. Однак така парадигма не забезпечує довготривалого успіху на ринку, а навпаки, призводить до повільного занепаду.

У таких умовах актуальності набувають проекти реінжинірингу - покращення управлінських і технологічних процесів на основі використання відповідних моделей і методів, а також найкращого досвіду. За допомогою реінжинірингу підприємства будівельної галузі зможуть за відносно короткий час привести свою систему управління до вимог сучасності, забезпечити свою конкурентоспроможність і закласти фундамент до постійного розвитку процесів. Це, у свою чергу, зробить систему управління більш ефективною, гнучкою, здатною до самовдосконалення.

Оскільки трансформація процесів управління відбувається в межах відповідного проекту, актуальною виявляється розробка моделей і методів реалізації таких проектів. 3 урахуванням додавання у проекти реінжинірингу ціннісної складової, такі моделі і методи можуть містити елементи наукової новизни.

Аналіз останніх досліджень. Головний тренд у розвитку управління проектами і програмами визначається стандартом РМВОК, остання на цей час редакція якого [1] дає чіткі уявлення про спектр моделей, методів, принципів, інструментів і засобів для використання при управлінні проектами. Однак, на жаль, у відповідному стандарті не відбито будівельну специфіку. Це було зроблено понад десять років тому, коли вийшла спеціальна редакція PMBOK для будівельних проектів (Construction Extension). Ціннісний вимір привнесений у проектний менеджмент японським стандартом Р2М [2], але у цьому стандарті наведено лише основи ціннісного підходу. Найкращі практики до використання в проектах зібрано у стандарті РЗМЗ [3] компанії Axelos, яка нині займається підтримкою та розвитком вже тра- 
диційного для проектного менеджменту стандарту PRINCE2. Однак у цих практиках спостерігається акцент на IT-проекти. 3 другого боку, в IT-сфері народилася методологія гнучкого управління Agile [4], яка нині активно використовується в проектній діяльності і за межами сфери IT. I якщо питання щодо їі використання в будівельних проектах є дискусійним, то застосування пї в проектах реінжинірингу є достатньо доречним. Питанням розвитку методології управління проектами займаються українські вчені С. Д. Бушуєв [5, 6], В. А. Рач [7], Ю. М. Тесля [8, 9] та інші. Однак питання ціннісно-орієнтованого управління проектами реінжинірингу будівельних підприємств вони не розглядали. Ціннісний підхід розвивається в роботах українських і зарубіжних вчених [10-12], однак його теж майже не застосовують до будівельної сфери. 3 другого боку, багато досліджень [13-15] присвячено розробці моделей і методів реінжинірингу, при чому викладаються як універсальні підходи [13], так і прикладні у застосуванні до певних галузей $[14,15]$, зокрема до будівельної [15]. Проте в цих дослідженнях не розглядається проблематика розробки моделей i методів ціннісно-орієнтованого управління проектами реінжинірингу будівельних підприємств і компаній, що обумовлює актуальність обраної тематики.

Метою статті $\epsilon$ формулювання концептуальної основи подальшого розвитку моделей і методів проектного менеджменту для ціннісно-орієнтованого управління проектами реінжинірингу будівельних компаній.

Виклад основного матеріалу. Для цілей ціннісно-орієнтованого управління проектами реінжинірингу будівельних компаній можна сформувати комбінований підхід, який поєднує три підходи: підхід проектної орієнтованості організацій (компаній), ціннісний підхід і підходи до реінжинірингу. Назвемо новий підхід тріадним підходом «проектність-цінність-реінжиніринг». В руслі кожної складової цього підходу окреслимо напрями досліджень для його створення, базуючись на виділенні не вирішених раніше частин проблеми у попередніх дослідженнях в межах кожного складового підходу.

Система управління проектом реінжинірингу має вбирати в себе моделі і методи кожної складової. Концептуальною основою для розробки моделей i методів ціннісноорієнтованого управління проектами реінжинірингу будівельних компаній може бути ви- ділення напрямів розробки кожного з елементів тріадного підходу «проектність-цінністьреінжиніринг» (рисунок 1).

У першому елементі «стандарти 3 управління проектами» недостатньо дослідженим є поєднання однієї з галузі знань стандарту РМВОК «управління інтеграцією в проекті» 3 гнучкою методологією Agile. Виникає напрям дослідження «інтеграція через Agile» (див. рисунок 1), розробка моделей і методів для якого в системі управління проектами реінжинірингу має базуватися на такому:

- розробка повного переліку вимог до продукту проекту реінжинірингу (product backlog) на початку проекту;

- ітераційна організація виконання проекту (через виконання короткотермінових спринтів - sprint);

- проведення огляду поточного спринту після його завершення і планування наступного на спеціальних нарадах команди проекту (retrospectives);

- проведення інтеграції усіх процесів управління проектом (управління часом, вартістю, якістю тощо) на таких нарадах.

При цьому останнє вимагає використання методу інтеграції, що має бути розроблений, на основі попередньо обгрунтованих чи створених моделей.

В другому елементі тріадного підходу «иіннісно-орієнтоване управління проектами» як перспективний можна окреслити напрям досліджень моделей і методів щодо життєвого циклу цінностей (див. рисунок 1).

На базі визначеної у стандарті з управління проектами і програмами для інноваційних підприємств Р2М [2] структури цінностей (цінності активу, цінності інновацій, цінності володіння для зацікавлених сторін, цінності інтелектуального активу) i 3 урахуванням специфіки будівельних компаній подальші дослідження можуть включати:

- категоризацію цінностей будівельних компаній, створення системи класифікації таких цінностей;

- розробку методу вибору пріоритетних цінностей для будівельної компанії з точки зору системи управлінських і технологічних процесів;

- категоризацію переліку цінностей, обраного за попереднім методом, з метою визначення підпроектів проекту реінжинірингу;

- визначення цільової динаміки цінностей за результатами проведення реінжи- 
нірингу, яка б включала балансування майбутніх інтересів зацікавлених сторін;
- формулювання місії, цілей і задач проекту реінжинірингу будівельної компанії.

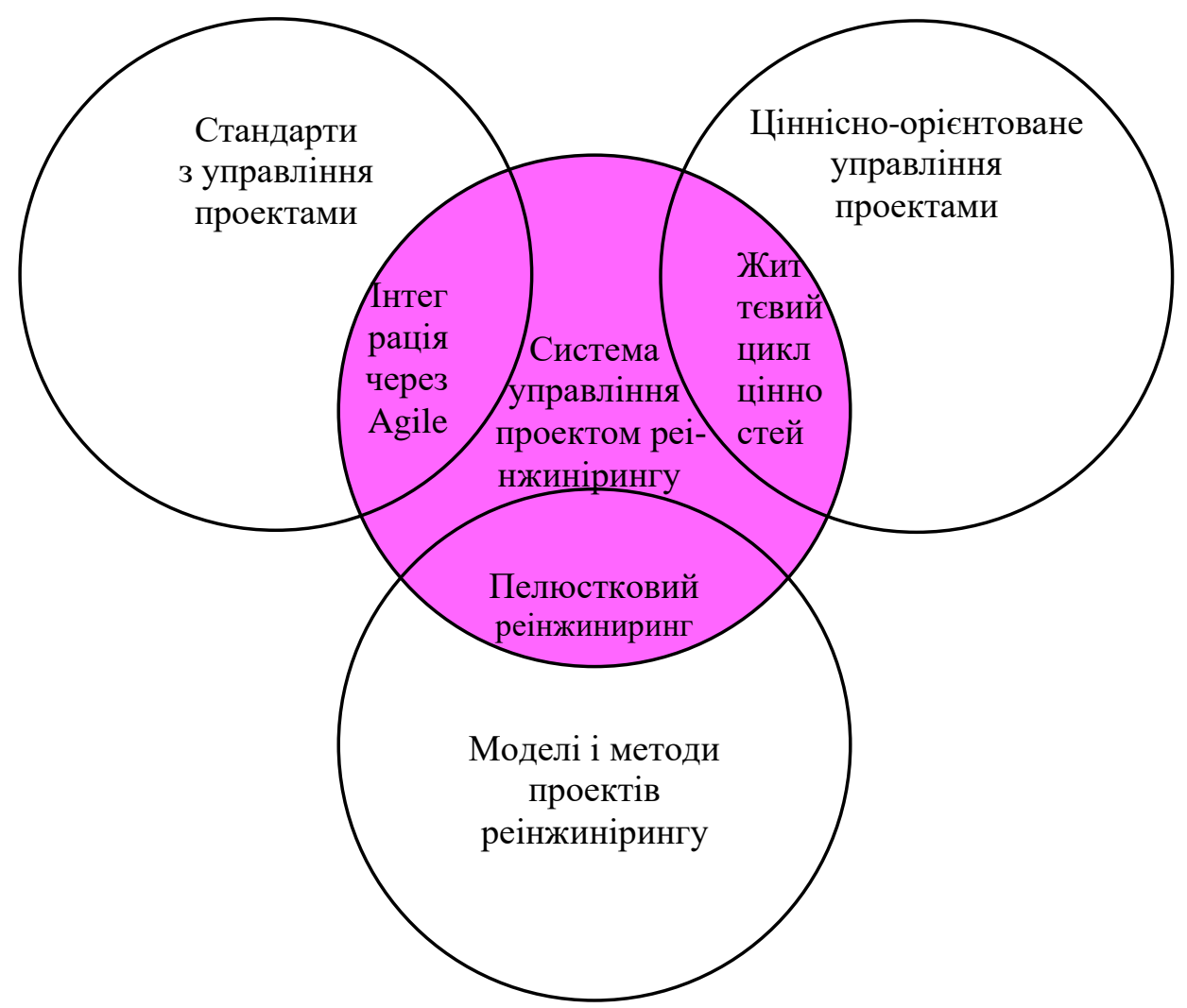

Рисунок 1 - Напрями розробки моделей і методів у проекті реінжинірингу

В третьому елементі описуваного підходу «моделі і методи проектів реінжинірингу» перспективним напрямом досліджень вбачається створення методу «пелюсткового реінжинірингу» (див. рисунок 1). Опишемо концепцію цього методу.

Оскільки предметом проекту реінжинірингу є процеси, що потребують вдосконалення, вхідним інформаційним потоком для системи управління проектом буде цільовий перелік процесів. Внаслідок того, що у другому елементі тріадного підходу визначені категорії цінностей будівельної компанії, згідно 3 такими категоріями будуть формуватися групи процесів, реінжиніринг яких буде становити зміст проекту.

Сутність пелюсткового реінжинірингу може бути визначена таким чином. Життєвий цикл проекту реінжинірингу має певні фази. За класичною методологією РМВОК [1] таких фаз має бути чотири (ініціалізація, планування, реалізація, завершення), хоча кожне підприємство може для своїх потреб визначати іншу кількість і наповнення фаз проекту. Для проектів реінжинірингу життевий цикл потребує подальшої розробки.

Представимо метод «пелюсткового реінжинірингу» таким, що складається 3 наступних етапів:

- визначення цільових параметрів проекту;

- аналіз діяльності підприємства, визначення проблемних місць (дублювання функцій і відсутніх функцій);

- визначення груп процесів для інжинірингу (на основі поєднання результатів аналізу проблемних місць і ціннісного аналізу);

- категоризація процесів за складністю всередині груп процесів;

- визначення «пелюсток» - переліку процесів 3 кожної групи процесів за параметром складності;

- початок життєвого циклу реінжинірингу для першої «пелюстки» - переліку найпростіших процесів;

- завершення першої фази реінжинірингу для першої «пелюстки» процесів, перехід на наступну фазу для цієї «пелюстки», початок першої фази реінжинірингу для другої 
«пелюстки» процесів (наступна за складністю група процесів);

- послідовне виконання реінжинірингу «пелюсток» процесів із запізненням кожної наступної на одну фазу - до повного завершення реінжинірингу усіх процесів - від найпростіших до найскладніших;

- підведення підсумків проекту реінжинірингу, винесення уроків, корекція моделей і методів реінжинірингу, впровадження постійного моніторингу процесів 3 метою, у тому числі, визначення необхідності ініціювання наступного проекту реінжинірингу.

Проведемо SWOT-аналіз запропонованого методу.

Сильними сторонами (S - strength) методу «пелюсткового реінжинірингу» є можливість урахування при вдосконаленні процесів більшої складності помилок і неточностей, які виявилися під час аналогічної фази процесів меншої складності.

Слабкими сторонами (W - weakness) методу є висока залежність змісту проекту (а отже, і висока ймовірність помилок в залежності) від визначення цільових груп процесів, яке відбувається на перших фазах проекту, причому прийняття рішення щодо цього грунтується на суб'єктивних оцінках.

Можливостями (O - opportunities) методу є створення ним підгрунтя до вимірності процесного управління в будівельній компаніï, що дає змогу проактивно передбачати необхідність впровадження чергового проекту реінжинірингу.

Загрозами ( $\mathrm{T}$ - threats) для методу є типовий для усіх проектів впровадження змін в компаніях спротив середньої ланки менеджменту. Для будівельних компаній ця загроза є ще більш актуальною, з огляду на середній вік фахівців середньої ланки та їх невисоку управлінську гнучкість.

Впровадження зазначеного методу в будівельних компаніях вимагає врахування специфіки будівельної галузі, зокрема, у частині:

- базової моделі процесів, яка, залежно від профілю будівельного підприємства, може включати: землевідведення, проектування, виробництво будівельних матеріалів і конструкцій, будівельну логістику, будівництво, управління фінансовими інструментами у будівельній галузі тощо;

- організаційної структури підприємства, яка, на відміну від більшості організаційних структур, як правило, є дивізіональною;
- рівня автоматизації управлінської діяльності (як правило, низького) й інтегрованості використовуваних IT-інструментів тощо.

Загалом, використання тріадного підходу «проектність-цінність-реінжиніринг» при плануванні і реалізації проектів реінжинірингу будівельних компаній дасть останнім змогу вдосконалити і осучаснити систему управління, що, у свою чергу, стане запорукою їх конкурентоспроможності.

Висновки. У статті визначено концептуальну основу подальшого розвитку моделей i методів проектного менеджменту для ціннісноорієнтованого управління проектами реінжинірингу будівельних компаній у вигляді тріадного підходу «проектність-цінність-реінжиніринг». Синергетичне поєднання моделей i методів кожного з елементів підходу, розробка нових моделей і методів для проектів реінжинірингу будівельних підприємств в межах цього підходу сприятиме вдосконаленню системи управління будівельними підприємствами (компаніями), підвищенню іiі ефективності. А це, в свою чергу, забезпечить можливість швидкого осучаснення менеджменту будівельної галузі і стане основою для його перманентного розвитку, що, з огляду на ключову роль будівництва, позитивно вплине на розвиток економіки країни в цілому.

Подальші розвідки у цьому напрямі можуть бути присвячені формалізації визначених у статті моделей і методів, тобто створенню методичного підгрунтя для ефективної реалізації ціннісно-орієнтованого управління проектами реінжинірингу будівельних компаній і підприємств.

\section{Список літератури}

[1] A Guide to the Project Management Body of Knowledge (PMBOK® Guide), sixth ed., USA, PMI, 2017.

[2] Руководство по управлению инновационными проектами и программами, т. 1, версия 1.2, пер. на рус. язык под ред. С. Д. Бушуева. Київ: Наук. світ, 2009.

[3] OGC (Office of Government Commerce). Portfolio, Programme and Project Management Maturity Model (P3M3). [Online]. Available: https://www.axelos.com/bestpractice-solutions/p3m3

[4] Agile Practice Guide. USA: Project Management Institute, 2017.

[5] С. Д. Бушуев, и Н. С. Бушуева, "Современные подходы к развитию методоло- 
гий управления проектами", Управління проектами та розвиток виробництвва: зб. наук. праць, № 1 (13), с. 5-19, Луганськ: Вид-во СНУ ім. В. Даля, 2005.

[6] С. Д. Бушуєв, Н. С. Бушуєва, та Д. І. Шороп, "Проектний офіс як методологія мультипроектного управління", Управління проектами та розвиток виробництва: зб. наук. праць, № 1 (9), с. 2431, Луганськ: Вид-во СНУ ім. В. Даля, 2004.

[7] В. А. Рач, "Управление проектами в контексте мировых тенденций развития науки", в X Міжнар. конф. Управління проектами у розвитку суспільства: тези доп. Тема: Управління проектами та програмами в умовах глобалізації світової економіки. Київ, 2013, с. 207-208.

[8] Ю. Н. Тесля, и А. А. Белощицкий, "Расширяющаяся Вселенная проектов", Вісник Черкаського державного технологічного університету, № 4, с. 67-71, 2011.

[9] Ю. М. Тесля, І. І. Оберемок, та О. Г. Тімінський, "Моделі і методи впровадження корпоративної системи управління проектами в девелопменті", Управління проектами та розвиток виробництва: зб. наук. праць, № 1 (29), с. 28-35, 2009.

[10] С. Д. Бушуев, . С. Бушуева, и Р. Ф. Ярошенко, "Модель гармонизации ценностей программ развития организаций в условиях турбулентности окружения", Управління розвитком складних систем, вип. 10, с. 9-13, 2012.

[11] О. М. Медведєва, "Ціннісно-орієнтоване управління взаємодією в проектах: методологічні основи", автореф. дис. д-ра техн. наук: 05.13.22, Київ, 2013.

[12] T. Gillier, S. Hooge, and G. Piat, "Framing value management for creative projects: an expansive perspective", International Journal of Project Management, vol. 33, iss. 4, pp. 947-960, 2005.

[13] M. Hammer, and J. Champy, Reengineering the corporation: a manifesto for business revolution. New York: Harper Business, 1993.

[14] С. В. Цюцюра, "Проектна реалізація стратегії управління підприємствами реінжинірингу енергоємних галузей", Управління проектами та розвиток виробництва: зб. наук. праць, № 2 (18), c. 110-114, Луганськ: Вид-во СНУ ім. В. Даля, 2006.
[15] Д. А. Монова, "Управління змістом та ризиками в проектах реінжинірингу будівельних споруд", автореф. дис. ... канд. техн. наук: спец. 05.13.22 - Управління проектами та програмами, Одес. нац. політехн. ун-т, Одеса, 2017.

\section{References}

[1] A Guide to the Project Management Body of Knowledge (PMBOK® Guide), sixth ed., USA, PMI, 2017.

[2] S. D. Bushuyev (ed.), Innovative project and program management guide, vol. 1, version 1.2. Kyiv: Nauk. svit, 2009 [in Russian].

[3] OGC (Office of Government Commerce). Portfolio, Programme and Project Management Maturity Model (P3M3). [Online]. Available: https://www.axelos.com/bestpractice-solutions/p3m3

[4] Agile Practice Guide. USA: Project Management Institute, 2017.

[5] S. D. Bushuyev, and N. S. Bushuyeva, "Modern approaches to the development of the project management methodologies", Upravlinnja proektamy ta rozvytok vyrobnyctva: coll. of sci. papers, no. 1 (13), pp. 5-19, Lugans'k: SNU im. V. Dalja, 2005 [in Russian].

[6] S. D. Bushuev, N. S. Bushueva, and D. I. Shorop, "Project office as a methodology of multi-project management", $U p$ ravlinnja proektamy ta rozvytok vyrobnyctva: coll. of sci. papers, no. 1 (9), pp. 24-31, Lugans'k: SNU im. V. Dalja, 2004 [in Ukrainian].

[7] V. A. Rach, Project management in the context of the world trends in the development of science", in Proc. Xth Internat. Conf. Project Management in the Development of Society. Subject: Program and Project Management in a Globalizing World Economy. Kyiv, 2013, pp. 207-208 [in Russian].

[8] Yu. N Teslya, and A. A. Beloshchytskiy, "Expanding universe of projects", Visnyk Cherkaskogo derzhavnogo tekhnologichnogo universytetu, no. 4, pp.67-71, 2011 [in Russian].

[9] Y. N. Teslya, I. I. Oberemok, and O. G. Timinsky, "Models and methods of implementation of corporate project management system in development", Upravlinnja proektamy ta rozvytok vyrobnyctva: coll. of sci. papers, no. 1 (29), pp. 28-35, 2009 [in Ukrainian]. 
[10] S. D. Bushuyev, N. S. Bushuyeva, and R. F. Yaroshenko, "The model of harmonization of values of organizations development programs in the conditions of environment turbulence", Upravlinnya rozvytkom skladnyh system, iss. 10, pp. 9-13, 2012 [in Russian].

[11] O. M. Medvedeva, "Value-oriented management by interaction in projects: methodological foundations", author's abstract of D.S. thesis: 05.13.22, Kyiv, 2013 [in Ukrainian].

[12] T. Gillier, S. Hooge, and G. Piat, "Framing value management for creative projects: an expansive perspective", International Journal of Project Management, vol. 33, iss. 4, pp. 947-960, 2005.
[13] M. Hammer, and J. Champy, Reengineering the corporation: a manifesto for business revolution. New York: Harper Business, 1993.

[14] S. V. Tsutsura, "The project realization of the strategy of management by reengineering enterprises of energy-capacious branches", Upravlinnja proektamy ta rozvytok vyrobnyctva: coll. of sci. papers, no. 2 (18), pp. 110-114, Lugans'k: SNU im. V. Dalja, 2006 [in Ukrainian].

[15] D. A. Monova, "Management by the content and risks in the projects of building constructions reengineering", author's abstract. of M.S. thesis: 05.13.22, Odesa, 2017 [in Ukrainian].

S. D. Bushuyev, Dr. Sc., professor, head of project management department, e-mail: sbushuyev@ukr.net

A. V. Puziichuk, postgraduate, e-mail: a.puziichul2018@meta.ua

Kyiv National University of Construction and Architecture, Povitroflotskyi ave., 31, Kyiv, 03037, Ukraine

\section{FURTHER DEVELOPMENT OF PROJECT MANAGEMENT MODELS AND METHODS FOR VALUE-ORIENTED MANAGEMENT BY THE PROJECTS OF CONSTRUCTION COMPANIES REENGINEERING}

Construction industry becomes very important for economic development. The importance of reengineering projects for ensuring the competitiveness of construction companies is determined. The analysis of literary sources according to three directions - standards and research in the field of project and program management; value approach; projects of management processes reengineering - is made. The triad approach "project-value-reengineering" is offered. The directions for the development of each of the elements of the "project-value-reengineering" approach for construction companies are highlighted. In the first element, this is integration through Agile, in the second one it is a life cycle of values, in the third one - petal reengineering. The steps of the "petal reengineering" method are proposed, SWOT-analysis of the method has been carried out. The conclusion concerning the increase of the flexibility of the system of construction companies management by introducing the method of "petal reengineering" is made. Prospects for further research in the chosen direction are outlined. Based on Japanese standard P2M, the structure of values includes asset values, values of innovation, ownership values for stakeholders, and intellectual property values. Taking into account the specifics of construction companies, further studies can include categorization of values of construction companies, creation of a classification system for such values, development of the method of choosing the priority values for a construction company in terms of the system of management and technological processes, categorization of the list of values selected by the previous method, in order to identify subprojects of the reengineering project, definition of target dynamics of values by the results of reengineering, which would include balancing of future interests of interested parties, formulation of mission, goals and objectives of the project of construction company reengineering.

Keywords: project management, value approach, reengineering, petal reengineering.

Стаття надійшла 25.06.2019

Прийнято 12.07.2019 